\title{
Front Matter: Volume 6445
}

, "Front Matter: Volume 6445," Proc. SPIE 6445, Optical Diagnostics and Sensing VII, 644501 (31 March 2007); doi: 10.1117/12.729068

SPIE. Event: SPIE BiOS, 2007, San Jose, California, United States 


\title{
PROGRESS IN BIOMEDICAL OPTICS AND IMAGING
}

Vol. 8, No. 22

\section{Optical Diagnostics \\ and Sensing VII}

\author{
Gerard L. Coté \\ Alexander V. Priezzhev \\ Editors
}

23-24 January 2007

San Jose, California, USA

Sponsored and Published by

SPIE-The International Society for Optical Engineering 
The papers included in this volume were part of the technical conference cited on the cover and title page. Papers were selected and subject to review by the editors and conference program committee. Some conference presentations may not be available for publication. The papers published in these proceedings reflect the work and thoughts of the authors and are published herein as submitted. The publisher is not responsible for the validity of the information or for any outcomes resulting from reliance thereon.

Please use the following format to cite material from this book:

Author(s), "Title of Paper," in Optical Diagnostics and Sensing VII, edited by Gerard L. Coté, Alexander V. Priezzhev, Proceedings of SPIE Vol. 6445 (SPIE, Bellingham, WA, 2007) Article CID Number.

ISSN 1605-7422

ISBN 9780819465580

Published by

SPIE-The International Society for Optical Engineering

P.O. Box 10, Bellingham, Washington 98227-0010 USA

Telephone 1 360/676-3290 (Pacific Time) · Fax 1 360/647-1445

http://www.spie.org

Copyright (C) 2007, The Society of Photo-Optical Instrumentation Engineers

Copying of material in this book for internal or personal use, or for the internal or personal use of specific clients, beyond the fair use provisions granted by the U.S. Copyright Law is authorized by SPIE subject to payment of copying fees. The Transactional Reporting Service base fee for this volume is $\$ 18.00$ per article (or portion thereof), which should be paid directly to the Copyright Clearance Center (CCC), 222 Rosewood Drive, Danvers, MA 01923. Payment may also be made electronically through CCC Online at http://www.copyright.com. Other copying for republication, resale, advertising or promotion, or any form of systematic or multiple reproduction of any material in this book is prohibited except with permission in writing from the publisher. The CCC fee code is $1605-7422 / 07 / \$ 18.00$.

Printed in the United States of America. 


\section{Contents}

vii Conference Committee

\section{SESSION 1 OPTICAL MONITORING OF GLUCOSE}

644502 Bedside monitoring of subcutaneous interstitial glucose in type 1 diabetic subjects using microdialysis and infrared spectrometry with optimal correlation to blood glucose concentrations [6445-01]

H. M. Heise, U. Damm, V. R. Kondepati, ISAS—Institute for Analytical Sciences, Univ. of Dortmund (Germany); J. K. Mader, M. Ellmerer, Medical Univ. Graz (Austria)

644504 Use of glycosylated dendrimer macromolecules to fluorescently monitor glucose concentration [6445-04]

H. T. Beier, B. L. Ibey, Texas A\&M Univ. (USA); M. V. Pishko, The Pennsylvania State Univ. (USA); G. L. Coté, Texas A\&M Univ. (USA)

\section{SESSION 2 OPTICAL ASSESSMENT OF BLOOD COMPONENTS: WHOLE BLOOD AND BLOOD FLOW}

644506 Depth sensitivity of laser Doppler perfusion imager: quantification based on experiments and Monte Carlo simulations on static and dynamic scattering phantoms [6445-06]

V. Rajan, B. Varghese, T. G. van Leeuwen, W. Steenbergen, Biomedical Technology Institute, Univ. of Twente (Netherlands)

644507 Real-time measurement of human blood flow with high temporal and spatial resolution [6445-07]

I. Menn, W. Wild, H. Aschemann, Univ. Rostock (Germany)

644508 An optical approach for non-invasive blood clot testing [6445-08]

V. Kalchenko, Weizmann Institute of Science (Israel); A. Brill, Hadassah Hebrew Univ. Medical Ctr. (Israel); I. Fine, Elfi-Tech Ltd. (Israel); A. Harmelin, Weizmann Institute of Science (Israel)

Pagination: Proceedings of SPIE follow an e-First publication model, with papers published first online and then in print and on CD-ROM. Papers are published as they are submitted and meet publication criteria. A unique, consistent, permanent citation identifier (CID) number is assigned to each article at the time of the first publication. Utilization of CIDs allows articles to be fully citable as soon they are published online, and connects the same identifier to all online, print, and electronic versions of the publication.

SPIE uses a six-digit CID article numbering system in which:

- The first four digits correspond to the SPIE volume number.

- The last two digits indicate publication order within the volume using a Base 36 numbering system employing both numerals and letters. These two-number sets start with 00, 01, 02, 03, 04, 05, 06, 07, 08, 09, 0A, 0B ... 0Z, followed by 10-1Z, 20-2Z, etc.

The CID number appears on each page of the manuscript. The complete citation is used on the first page, and an abbreviated version on subsequent pages. 
644509 Erythrocytes volume and refractive index measurement with a digital holographic microscope [6445-09]

B. Rappaz, Brain Mind Institute, EPFL (Switzerland); A. Barbul, Sackler Faculty of Medicine (Israel); F. Charrière, J. Kühn, Imaging and Applied Optics Institute, EPFL (Switzerland); P. Marquet, Ctr. de Neurosciences Psychiatriques, DP-CHUV (Switzerland); R. Korenstein, Sackler Faculty of Medicine (Israel); C. Depeursinge, Imaging and Applied Optics Institute, EPFL (Switzerland); P. Magistretti, Brain Mind Institute, EPFL (Switzerland) and Ctr. de Neurosciences Psychiatriques, DP-CHUV (Switzerland)

64450A Optical sensor technology for a noninvasive medical blood diagnosis [6445-10] J. Kraitl, H. Ewald, Univ. of Rostock (Germany); H. Gehring, Clinic of Anesthesiology, Clinic $\mathrm{S}-\mathrm{H}$, Campus Luebeck (Germany)

64450B A method for the prevention of high-risk medication errors [6445-11]

D. Allgeyer, Consultant (USA)

\section{SESSION $3 \quad$ TISSUE DIAGNOSTICS AND MOLECULAR SENSING}

64450D The impact of blood content on skin spectra [6445-13]

R. Chen, Y. Li, H. Lin, B. Huang, G. Chen, S. Feng, Fujian Normal Univ. (China)

\section{POSTER SESSION}

64450 Prediction of blood glucose using interstitial fluid extracted by ultrasound and vacuum [6445-05]

D. Li, H. Yu, X. Huang, F. Huang, X. Hu, K. Xu, Tianjin Univ. (China)

64450J Monte Carlo modeling and phantom study for implantable fluorescent analyte sensors for human head [6445-17]

Q. Wan, H. T. Beier, B. L. Ibey, Texas A\&M Univ. (USA); T. Good, Univ. of Maryland, Baltimore County (USA); G. L. Coté, Texas A\&M Univ. (USA)

64450K Noninvasive blood glucose measurement using multiple laser diodes [6445-18] E. T. Ooi, X. Q. Zhang, J. H. Chen, P. H. Soh, K. Ng, J. H. Yeo, Glucostats System (Singapore)

64450L Methodology of effective glucose-specific signal extraction in complicated sample [6445-19]

W. Chen, B. Deng, R. Liu, X. Gu, K. Xu, Tianjin Univ. (China)

$64450 \mathrm{M}$ Applying the floating-reference method to improve the precision of noninvasive blood glucose measurement [6445-20]

W. Chen, Z. Ma, L. An, K. Xu, Tianjin Univ. (China)

64450N High-resolution surface plasmon resonance biosensing system for glucose concentration detecting [6445-21]

X. Huang, D. Li, H. YU, F. Huang, X. Hu, K. Xu, Tianjin Univ. (China)

$64450 Q \quad$ A preliminary study on determining the time window of hypothermia cerebral protection in rat cortex by laser speckle flowmetry [6445-24]

W. Wang, Q. Li, S. Zeng, Q. Luo, P. Li, Huazhong Univ. of Science and Technology (China) 
64450R Elicitation interval dependent spatiotemporal evolution of cortical spreading depression waves revealed by optical intrinsic signal imaging [6445-25]

S. Chen, H. Gong, S. Zeng, Q. Luo, P. Li, Huazhong Univ. of Science and Technology (China)

64450S Classification of the degenerative grade of lesions of supraspinatus rotator cuff tendons by FT-Raman spectroscopy [6445-26]

B. Palma Fogazza, C. da Silva Carvalho, S. Godoy Penteado, Univ. do Vale do Paraíba (Brazil); C. S. Meneses, CIPAX-Medicina Diagnóstica (Brazil); A. Abrahão Martin, H. da Silva Martinho, Univ. do Vale do Paraíba (Brazil)

64450T Analysis of biomedical time signals for characterization of cutaneous diabetic micro-angiopathy [6445-27]

J. Kraitl, H. Ewald, Univ. of Rostock (Germany)

$64450 \mathrm{U}$ Optical glucose sensing in biotissue phantom by diffuse reflectance technique [6445-29] M. Yu. Kirillin, A. V. Bykov, M.V. Lomonosov Moscow State Univ. (Russia) and Univ. of Oulu (Finland); A. V. Priezzhev, M.V. Lomonosov Moscow State Univ. (Russia); R. Myllyla, Univ. of Oulu (Finland)

$64450 \mathrm{~V}$ Refractive index detection with self-mixing interferometry for biosensing applications [6445-30]

M. Määttälä, M. Wang, L. Krehut, Univ. of Oulu (Finland); J. Hast, VTT Technical Research Ctr. of Finland (Finland); R. Myllylä, Univ. of Oulu (Finland)

64450W PDMS microdevice with built-in optical biosensor array for on-site monitoring of the microenvironment within microchannels [6445-31]

L. Zhang, K. Y. Cheung, Y. R. Chua, D. Trau, National Univ. of Singapore (Singapore)

64450Y Hydrogel micro-arrays for multi-analyte detection [6445-33]

R. M. Rounds, S. Lee, Texas A\&M Univ. (USA); S. Jeffords, Louisiana Tech Univ. (USA); B. L. Ibey, Texas A\&M Univ. (USA); M. V. Pishko, The Pennsylvania State Univ. (USA); G. L. Coté, Texas A\&M Univ. (USA)

Author Index 
Downloaded From: https://www.spiedigitallibrary.org/conference-proceedings-of-spie on 26 Apr 2023

Terms of Use: https://www.spiedigitallibrary.org/terms-of-use 


\title{
Conference Committee
}

\author{
Symposium Chairs \\ James Fujimoto, Massachusetts Institute of Technology (USA) \\ R. Rox Anderson, Wellman Center for Photomedicine (USA), \\ Massachusetts General Hospital (USA) and Harvard Medical School \\ (USA)
}

Program Track Chairs

Ammasi Periasamy, University of Virginia (USA)

Daniel Farkas, Cedars-Sinai Medical Center (USA)

Conference Chairs

Gerard L. Coté, Texas A\&M University (USA)

Alexander V. Priezzhev, M.V. Lomonosov Moscow State University (Russia)

Program Committee

Rafat R. Ansari, NASA Glenn Research Center (USA)

Werner Gellermann, The University of Utah (USA)

Yuri I. Gurfinkel, Central Clinical Hospital (Russia)

Jürgen Lademann, Charité-Universität Medizin Berlin (Germany)

Michael J. McShane, Texas A\&M University (USA)

Kenith E. Meissner, Texas A\&M University (USA)

Risto A. Myllylä, University of Oulu (Finland)

Gert E. Nilsson, Linköping University (Sweden)

Jeffery S. Reynolds, Bayer Healthcare (USA)

Wiendelt Steenbergen, Universiteit Twente (Netherlands)

Kexin Xu, Tianjin University (China)

Shaoqun Zeng, Huazhong University of Science and Technology (China)

Dmitry A. Zimnyakov, Saratov State University (Russia)

\section{Session Chairs}

1 Optical Monitoring of Glucose

Gerard L. Coté, Texas A\&M University (USA)

Michael J. McShane, Texas A\&M University (USA)

2 Optical Assessment of Blood Components: Whole Blood and Blood Flow Alexander V. Priezzhev, M.V. Lomonosov Moscow State University (Russia)

3 Tissue Diagnostics and Molecular Sensing

Michael J. McShane, Texas A\&M University (USA) 
Downloaded From: https://www.spiedigitallibrary.org/conference-proceedings-of-spie on 26 Apr 2023

Terms of Use: https://www.spiedigitallibrary.org/terms-of-use 